
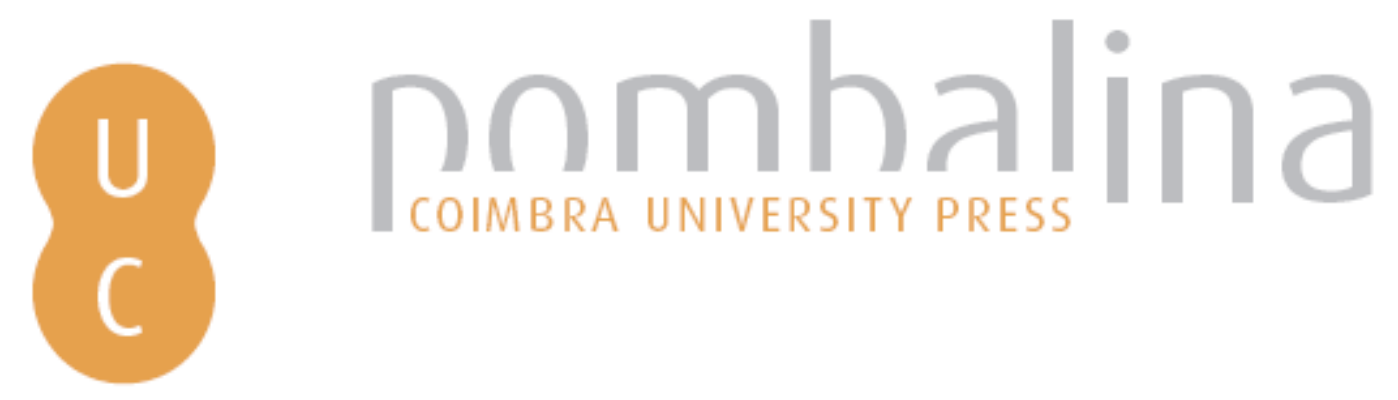

\title{
Planning and purism: ideological forces in shaping linguistic identity
}

\author{
Autor(es): Vihman, VirveAnneli \\ Publicado por: Imprensa da Universidade de Coimbra \\ URL \\ persistente: $\quad$ URI:http://hdl.handle.net/10316.2/43209 \\ DOI: $\quad$ DOl:https://doi.org/10.14195/978-989-26-1483-0_2
}

Accessed : $\quad$ 26-Apr-2023 14:51:04

A navegação consulta e descarregamento dos títulos inseridos nas Bibliotecas Digitais UC Digitalis, UC Pombalina e UC Impactum, pressupõem a aceitação plena e sem reservas dos Termos e Condições de Uso destas Bibliotecas Digitais, disponíveis em https://digitalis.uc.pt/pt-pt/termos.

Conforme exposto nos referidos Termos e Condições de Uso, o descarregamento de títulos de acesso restrito requer uma licença válida de autorização devendo o utilizador aceder ao(s) documento(s) a partir de um endereço de IP da instituição detentora da supramencionada licença.

Ao utilizador é apenas permitido o descarregamento para uso pessoal, pelo que o emprego do(s) título(s) descarregado(s) para outro fim, designadamente comercial, carece de autorização do respetivo autor ou editor da obra.

Na medida em que todas as obras da UC Digitalis se encontram protegidas pelo Código do Direito de Autor e Direitos Conexos e demais legislação aplicável, toda a cópia, parcial ou total, deste documento, nos casos em que é legalmente admitida, deverá conter ou fazer-se acompanhar por este aviso.

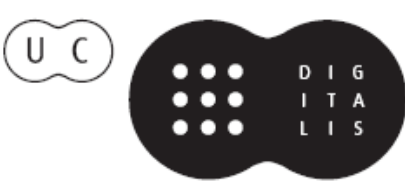




\section{IDENTITY(IES) A MULTICULTURAL AND MULTIDISCIPLINARY APPROACH}

\section{ANA PAULA ARNAUT \\ (ORG.)}

IMPRENSA DA UNIVERSIDADE DE COIMBRA

COIMBRA UNIVERSITY PRESS 
PLANNINGANDAURISM: IDEOLOGICAL FORCES I N S HAPING LINGUISTIC I D E N T I T Y Y I

Virve-Anneli Vihman, University of Tartu

\begin{abstract}
National identity is typically conservative, reflecting a collective understanding and carried by symbols and signs that have had time to take root. Yet, history has shown that groups can follow very different paths to emerging awareness of ethnic, national, or other group identity. Norms articulated from a central authority may reflect values embraced by the group represented, or else may impose a novel or external value system. Hence, top-down normativity can serve to support or change group identity, but it is not necessarily conservative. This paper looks at both innovative and conservative normativity in language planning across two centuries of formation of a conscious Estonian national identity. This time period includes most of the period during which the awareness of Estonian national identity developed. Various
\end{abstract}

${ }^{31}$ I note that this paper is based on an idea originally conceived jointly with Martin Ehala, and thank him for commenting on an earlier draft of the paper. I would also like to thank Ana Paula Arnaut, fellow members of the Culture, Arts, and Humanities task force of the Coimbra Group of Universities, and the participants in the Identity(ies) seminar at Coimbra University in November 2013, for many thought-provoking discussions. 
sub-periods within that time show how political practices with regard to language planning reflect differences in values of the periods in question. Throughout this time period, rhetoric on the part of official language planners as well as ideologues and activists has placed Estonian identity in opposition to external models, typically German or Russian national identity, and in affinity with Finnish models. In a country the size of Estonia, whose population is currently under 1.3 million, and in a context of constant foreign contacts and influences, it is no surprise that national identity is constructed in comparison and contrast to other nations.

Keywords: National Identity, Language Planning, Language Reform, Estonia

\section{Background: Two centuries of Estonian national identity formation}

The generally accepted narrative of the emergence of Estonian national awareness includes the notion of a dark "folktale" past, in which the Estonian people toiled on the land while ruled by various foreign powers (particularly Denmark, Sweden, Germany, and Russia). The centuries preceding the nineteenth are conceived of as a time of serfdom, when Estonian peasants worked the land for foreign landowners. Importantly, during the eighteenth and much of the nineteenth century, when the foreign landowners and political and cultural leaders were German, it was also true that Estonian peasants who gained access to schools and education became Germanised, both linguistically and culturally. Hence, Estonian was a language of the uneducated peasants. 
The 1800s, however, saw a National Awakening in Estonia. This national movement, as so many others in Europe, drew on the Herderian notion that language defines a cultural group and the linguistic commonality underlies political claims to national enterprises and the moral right to nation-building (Fichte, 1845; Leerssen, 2006: 100). The model was similar across Europe: "cultural nationalism creates a new sense of belonging together and homogeneity by articulating a common cultural identity, inventing traditions and constructing a shared cultural memory. This provides the intellectual climate and the arguments from which a sense of empowerment and agency in the political field can arise and political nationalism can develop" (Vihman and Barkhoff, 2014: 4).

The Baltic-German and emerging Estonian intelligentsia began to take an interest in the empowerment and liberation of Estonians, and began placing importance on Estonian culture, following the patterns seen in Germany and the kinship nations of Hungary and Finland. This new sense of cultural value and importance had enormous effects on Estonians' social mobilisation and national awareness, as well as, inevitably, the perceived need for language standardisation.

However, Estonia still formed part of the Russian empire at this time, and a backlash occurred in the mid-1880s with the Russification of the Baltic provinces. This was mostly directed against German, the language of the cultural elite and higher education, but the aggressive policy of Russification had effects on local languages as well. The use of Estonian in schools, for instance, was restricted to religion and language ("mother tongue") teaching. The Russification process slowed down in the 1900s and was brought to a halt in 1918, when the Republic of Estonia was established for the first time. The founders of the fledgling republic clearly drew the connection between linguistic and national identity. The new independence fuelled energy for reforming the language as a marker of national identity, and led to 
a newly articulated need for language standardisation. The language reform movement is discussed below.

The newly achieved independence lasted only until World War II, when the Baltic countries were annexed by the Soviet Union. The Soviet occupation continued until 1991, when all three Baltic countries reestablished independence. By now, the second period of independent statehood has lasted longer than the earlier, interregnum period. All three Baltic countries have been members of both the EU and NATO since 2004. In the multicultural world of today, amid EU policies which support a broad approach to citizenship, the language question is necessarily discussed in quite different terms than earlier. Perceived threats to the national languages, though they may include the Russian language spoken by large domestic minorities, come just as clearly from communication and entertainment technology which knows no borders. Attitudes toward the Russophone population in Estonia have changed during the post-Soviet period, but still tend to be rooted in assimilationist cultural models (Kruusvall, Vetik and Berry, 2009).

It may be helpful to look at different phases of approaches to language policy and planning along the road to full European membership, and the distinction of belonging to an elite group of languages with its own higher educational system, national government and translations of Microsoft software programmes, rare for such small linguistic populations. Today, much discussion regarding language policy and identity revolves around whether Estonian identity has shifted (or might shift) to include a broader, more inclusive approach to belonging (e.g. articles in popular media such as Ehala, 2011; Piirimäe, 2013; Valk, 2011; Vetik, 2011), or whether this rhetoric is just Euro-friendly political correctness, masking a more intolerant, inward, nationalist construction of identity (Sutrop, 2008; Helme, 2011). 


\section{Language planning}

This paper focuses on two examples of innovative, progressive language planning and two examples of conservative planning, rooted in tradition and norms based on the past, all drawn from two centuries of Estonian nation-building. I use the term 'planning' to include language management and corpus planning as well as prescriptive language policy, but I also make reference to language practices and beliefs (cf Spolsky, 2004: 5; Walsh, 2014).

\subsection{Innovative planning}

The examples of innovation in language normativity come from the mid-nineteenth and the early twentieth century. Both of these periods witnessed enthusiastic movements for language reform which echoed and bolstered the search for a distinct, defining character for Estonian identity to consolidate the emerging nation. The example of Finnish language reform was seen as a model, and served as a source of inspiration for Estonian language reformers, based on geographic and cultural proximity as well as ethnic and linguistic kinship. However, Estonian language reformers in the twentieth century had farther-reaching ambitions than the Finnish reformers and at least one, Johannes Aavik, made his mark on history for demonstrating how thoroughly a single person could affect language usage.

\subsubsection{New orthography}

As mentioned above, the mid-nineteenth century was a crucial period of nation-building across Europe. The emerging consciousness

of Estonian character and culture as distinct from elite German 
landowner culture required the discovery of and emphasis on unique Estonian cultural symbols. The national movement also inherently involved linguistic awareness and reform. In the mid-1800s, a lively debate transpired over orthography. As education had involved Germanisation, at least until the 1830s (Kurman, 1968: 21), early writings in Estonian were produced by either Germans who were second-language learners of Estonian, or else Estonians whose education had taken place in German.

Hence, what became known as the "Old Orthography" was based on German, but it was also advocated by prominent Estonian cultural figures like J.V. Jannsen (1819-1890), who founded the first regularly published Estonian-language newspaper, wrote the words to the Estonian national anthem, and played a prominent role in the National Awakening. The flaws with the Old Orthography had been pointed out already in the early nineteenth century (e.g. Rosenplänter, 1813, cited in Kurman, 1968: 23). Most importantly, it was based on German, and hence it was phonetically and phonologically inappropriate for representing Estonian. The phonological dissimilarity of the languages required a different orthographic logic. The Old Orthography was, however, a standardised system, and although it was based on German, systematic rules had been devised to account for peculiarities of Estonian phonology (see Laanekask and Erelt 2003: 287-292). Indeed, variation increased toward the end of the nineteenth century after the new orthography was adopted, involving both variation in how orthographic rules were interpreted as well as variation in language usage in the written language, as the numbers of people writing in Estonian multiplied, and writers drew on various Estonian dialects as well as foreign languages.

As early as 1820, Otto Wilhelm Masing set forth proposals for reforms in both vocabulary and the writing system, among which the most important and longest-lasting was the introduction of the letter Õ, still alive and well in modern Estonian. Masing himself (1763- 
-1832) is a good example of a Germanised Estonian, who was said to be of Swedish and Estonian extraction, yet "stoutly maintained throughout his adult life that he was a German" (Kurman, 1968: 21). Many of Masing's proposed reforms never took effect, but the letter Õ was officially brought into use in 1870 , and became the most distinguishing feature of the Estonian alphabet. Masing's insight was popularised by the help of support from men of letters F.R. Kreutzwald and F.R. Faehlmann, and by mid-century, it was in general use. Masing wrote in his first treatise on language that Estonian is in need of a letter corresponding to the Russian b. It is noteworthy that Finnish, the model for so much of written Estonian and Estonian linguistic reforms, lacks this sound and letter; generally, Estonian phonology is much more similar to Finnish than Russian.

Although many of Masing's proposals were not adopted, the process he initiated led to thorough spelling reforms after a period of cultural stagnation in the 1830s. A struggle began in the 1850 s between the Old and New Orthographies which was to last for a quarter of a century. Friedrich Reinhold Kreutzwald's conversion to the new system and publication of the national epic Kalevipoeg in the new orthography was a crucial victory for the spelling reform movement. Kreutzwald also played an important role as an energetic advocate of the new spelling. Another important argument was economy: the new spelling system was more efficient and saved space, which bore some weight in winning over publishers.

Estonian social structure underwent a period of modernisation in the 1860 s, involving urbanisation and greater social mobility, as peasants began to own land and become merchants after non-guild members were granted the right to trade. The new orthography came in bit by bit, as a new, native Estonian intelligentsia developed, and as new converts came to see that the new system was more fitting for Estonian phonology. In 1866, even Jannsen, who continued to publish his newspaper, Eesti Postimees, in the Old Orthography, 
privately admitted that the new system was preferable (Kurman, 1968: 31). The first national song festival was held in Tartu in 1869, which constituted a manifestation of national and cultural awakening. Changes in general orthographic usage took root fairly rapidly following that year, reflecting the speed of social changes. In 1869 , only $20 \%$ of printed works used the new orthography. By 1872, Jannsen adopted the new orthography in his newspaper, and about half of the books published used the new spelling; by 1875 , the proportion was $75 \%$, and the new orthography gained ground rapidly after this. The 1860 s are known as the most intense period of National Awakening, and the new, distinctive orthography was symbolically well suited for a new, distinct national identity.

However, as the new orthography gained ground after 1875, it also increased in diversity. Advocates adopted the new spelling variously and proceeded to modify it further. As growing numbers of Estonians began to write, writers from different parts of the country employed the orthography in various ways, reflecting both regional dialect variation and differences in interpretation. Hence, even as the new sense of Estonian identity brought spelling reforms and a new sense of ownership of the written language, the absence of a normalising grammar became increasingly felt. In addition to the general diversity in spelling, South Estonian writers clung to the Old Orthography. The struggle was seen to reflect pro-German Westernism versus Slavophilia, and its resolution in the 1860s-1870s only led to a renewed need for more thorough standardisation and/ or reform.

\subsubsection{Language renewal}

The quest for a new orthography was intricately linked to the developing awareness of Estonian identity, linking national and 
linguistic identity and framed as a liberation of the written language from the ill-fitting models used earlier. In the early twentieth century, however, the debates over language reform applied to broader linguistic issues, and again language reformers themselves were split between various approaches to language normativity. As earlier, the language question was intimately related to the national question. Finnish was no longer so much a model for language reform, but was seen, rather, as a source to draw from for linguistic enrichment. The language reform movement coincided with a greater social and political movement, leading to and including Estonia gaining independence in 1918. During this time, amid economic progress and cultural empowerment, the language regulators and the language renovators battled for the last word.

Two publications of importance for the story of language planning in Estonia appeared in 1912. Johannes Voldemar Veski authored the first normative guidelines for written Estonian in a pamphlet, 'Rules for written Estonian', in which he introduced to the wider public the decisions reached at the recent linguistic conferences. Veski based his rules on the principles of scientific accuracy and faithfulness to the way people actually speak, hence his rules supported the notion of Estonian identity and uniqueness, but they were conservative, intended to preserve the way Estonian had developed and drawing on Estonian varieties rather than foreign languages (eschewing even Finnish) for lexical enrichment (Raag, 1998: 32-25; Kurman, 1968: 65-67).

In the same year Johannes Aavik introduced his programme for "language renewal", which is considered to be more radical than those of other language reformers (Raag, 1998: 25-26). Indeed, Aavik secured a place in history for the way in which he, as an individual language planner, affected the Estonian language, campaigning for radical changes on all levels of language (see Chalvin, 2010; Ehala, 1998; Raag, 1998). Aavik's guiding principles 
were beauty, clarity, and faithfulness to origins (phonological historicity). Language reform movements in Europe tended to be concerned with spelling and word coinage. The Estonian language reforms of the early twentieth century did involve neologisms, but Aavik's proposals - and his long-term influence - went much further. His proposed changes not only targeted the lexicon, but also introduced syntactic and morphological innovations.

The need for standardisation and norms was acutely felt by this point. A central authority was needed to guide the process; two organisations (Eestimaa Rahvahariduse Selts 'Society for Public Education in Estonia' and Eesti Kirjanduse Selts 'Estonian Literary Society') had been established which combined efforts to standardise the language. Linguistic conferences had been organised, but they moved at a slow pace (four meetings in four years) and the implementation of their decisions depended on how much authority they were seen to possess. The decision was taken to compile a prescriptive dictionary, but the diverse reception of norms issued meant that the language planners had to not only arrive at agreement and issue decisions on correct usage, but also had to establish their authority and compel writers and publishers to follow their decisions. Many of the debates resulted in parallel (inflectional) forms being included in the dictionaries of correct usage, leading to a situation where "not a single Estonian is capable of writing Estonian without the help of a dictionary. This state of affairs comes from the differences between the spoken language and the norm language, and from the changes to the norm which occur occasionally" (Tauli, 1940: 228).

Aavik published a book criticising the language usage of contemporary poets, in which he claimed that "before Kreutzwald and Koidula, errors in usage were made under the pretext of poetic license; now, to a certain extent, they are made in the name of, and under the cover of, language reform". Kurman cites an optimistic 
nugget from this book, in which Aavik advises poets: "Do not write poetry! Thereby you will only squander your talent and gifts... wait [instead] for a number of decades until the [literary] language has been completely formed" (Aavik, 1922, translation from Kurman, 1968: 77). Considering the speed of language change and the amount of debate still ongoing today, nearly a century later, the poets would certainly have kept from squandering their talents had they waited for a "completely formed" literary language to write in.

The language issue caused much disagreement among the Estonian intelligentsia, and led to the development of two main camps for action: the regulators, led by J. V. Veski, who promoted "unhurried evolution" (Raag, 1998: 34) and the revolutionaries led by Johannes Aavik, who demanded major linguistic changes to match the revolutionary social changes of the time. A third camp advocated self-regulation. The following passages by Veski illustrate the regulators' approach to language planning:

Language is in a way a living being: it sprouts, develops and grows at the same time as it shakes off decaying parts [...] but always enriching itself with new ingredients and conceptions, and thereby acquiring greater flexibility and subtler shades of expression...

All elements, plans and rules needed for the further development of Estonian lie hidden in our language itself, as a member of the original Finno-Ugric language family. (Veski, 1913: 99-100, translation from Raag, 1998: 34)

Intriguingly, Aavik used a different metaphor, which evokes the revolutionary and industrial leanings of the times: he urged the reader to see language first and foremost as an implement for human dealings, a tool, a MACHINE, the aim of which is to express thoughts, and also often to achieve aesthetic effects!" (Aavik, 1924: 8, my translation) He claimed that one should look at it as an engineer, 
"who tries to bend and use phenomena to his/her own advantage" (Aavik, 1924: 8-9). Aavik determined to improve the language, nearly singlehandedly, basing his campaign on his principles of "good" Estonian language: beauty, simplicity, and faithfulness to Finno-Ugric roots. Ideally, change would be based on all three principles, but if pressed, beauty would trump the other two. He drew from elements of Estonian, including the dialects, as well as foreign elements, mainly Finnish, which he saw as providing an ideal source of language enrichment which was nevertheless true to the original, Finno-Ugric character of Estonian. It must be said, however, that he also created many neologisms ex nihilo, less typical of the language reform movements of the day than borrowing from foreign or kindred linguistic sources.

(In addition to lexical innovations, Aavik introduced or advocated the use of particular morphological forms, even in linguistic categories as basic as plural formation (proposing a "vowel plural" alternative to the ordinary, sometimes lengthy plural form, e.g. example 1); superlative formation (the synthetic superlative, which shortened lengthy, superlatives, ex. 2), and a short illative formed through fusional means, to reduce the proliferation of the "terrible and ugly s-es" imposed by the agglutinative illative -sse (ex. 3, Raag, 1998: 66-67). All of these existed in some regions of Estonia, and were to a greater or lesser extent known to speakers of Standard Estonian, but Aavik promoted their much broader implementation).

1. Vowel plural:

õnnelik-e

happy/lucky-PL.GEN

2. Synthetic superlative:

ilusa-im vs. analytic:

pretty-SUPERLATIVE vs. long plural:

õnnelik-ku-de

happy/lucky-PL-GEN

kõige ilusa-m

most pretty-COMPARATIVE 
3. Short illative:

vs. agglutinative: jõe-sse

a. jõkke

river.ILL

river-ILL

b. kiriku

vs. agglutinative: kiriku-sse

church.ILL

church.ILL

Aavik also proposed, for instance, changes in word order, particularly the "de-Germanisation" of subordinate clauses, and the reduction of certain "ugly" phonemes, such as /t/ and /s/. He advocated his reform and enthusiastically campaigned to bring changes into common usage through linguistic treatises and literary translations. Raag investigates the extent to which Aavik's proposals took effect, and shows that indeed, each of these did, to some extent, affect Estonian in the long term, despite the fact that Aavik went into exile in 1944, hence losing some effective power as an active example for advocating his preferred linguistic choices.

\subsection{Conservative planning}

While the periods of innovation coincided with the nation-building project and social progressivism of the times, the periods of conservative language planning we turn to now are less united by a single ethos. However, they can both be understood in the light of responding to a perceived threat. That threat was obvious in the policies and totalitarianism of the Soviet period. In the early 2000s, the perception of a threat may be more open to interpretation, but it derived from both the domestic non-Estophone population and the external influences coming from English and Europeanisms in all spheres of life. 


\subsubsection{Soviet language planning}

The conservative language policies of the Soviet period served two ends, as was necessary in order to satisfy both the local Estonian authorities as well as the ultimate seat of power in Moscow. This period was characterised by strengthened central control over society, including greater control over language usage. Language policy included forced migration of people from across the Soviet Union (Kamusella, 2009: 36-37; curiously, not mentioned in Comrie, 1981), as well as the introduction of Russian and the Cyrillic alphabet in all levels of officialdom, from the linguistic landscape in cities and towns (bilingual street signs, many shop and other signs only in Russian) to official paperwork, much of which was only acceptable if completed in Russian, as well as the compulsory teaching of Russian in schools (Kamusella, 2014; Verschik, 2008: 26-30). Stricter control was exacted over printed matter in any language, however: this included censorship regarding the content but also a stringent demand for linguistic conformity, in Estonian texts as well as Russian ones (even as early as 1941).

In the pre-Soviet period, trained philologist editors had emerged as a new vocation, partly as a result of the development of the Estonian-language university and support for the field of Estonian philology. However, this was often seen by publishers and editors as an unnecessary expense, and was waived in favor of greater freedom and less restriction. Indeed, freedom of language use reigned in the Estonian press until Soviet times (Raag, 1998: 39).

The "Sovietisation" of governance and bureaucracy changed this. In the media and press, Sovietisation meant extensive "linguistic precorrection" of all printed matter, which was not systematically questioned until the late 1980s, when the Singing Revolution was ushered in on waves of anti-Soviet feeling in society and a rising general confidence and courage to protest the political order. 
Meanwhile, in the Soviet Union, every newspaper had mandatory positions for editors of linguistic correctness, and every published piece of writing underwent not only political, but also linguistic correction and was subject to approval (Elisto, 1948: 67).

Tellingly, the reformer J. Aavik fled to Sweden in 1944 (along with other important figures in linguistics and language planning, such as A. Saareste and V. Tauli), while the language regulator J.V. Veski stayed in Soviet Estonia, and this too had an effect on the language planning of the times. The Estonian Literary Society was abolished in 1941, but the Mother Tongue Society was allowed to continue its activities. Language planning suffered a "drastic decline" (Laanekask and Erelt, 2003: 321) as the earlier planners, especially Aavik, were denounced as having made serious errors. The language reform was labelled a "bourgeois language reform" and said to "have served reactionary forces and not the interests of common people" (Laanekask and Erelt, 2003: 321-322).

The parallel forms given approval for usage, which had been admissible and advocated by Aavik as enabling more choice and richer expressiveness for language users, were now greatly reduced in the Dictionary of Correct Usage: the "prevailing trend was to fight against 'useless parallel forms' and for 'popular language"” (Laanekask and Erelt, 2003: 322). Maintaining correctness across all forms of printed matter entailed certain decisions regarding preferred usage, and the Dictionary of Correct Usage reflected this as well as enforcing it. "Rigidity was further intensified in a totalitarian society by the common understanding that if a speech form is not listed in the 'linguistic Bible', it is not a correct speech form" (Laanekask and Erelt, 2003: 322).

Language regulation during this period served a paradoxical duality of purpose. The authoritarian, controlling approach was clearly a tool for totalitarian authority, as was the reduction in the number of publishers as well as organisations mandated to work on 
language issues. Estonian corpus planning, however, was defensive and purist. As far as it was able, it reacted to the influx of Russian terms and the dominance of the Russian language in Estonia, and used regulation of Estonian as a form of resistance. Maintenance of Estonian culture and traditions was seen in Estonia as tool for resistance in general, amidst heavy Russian linguistic influence via education, entertainment and immigration. Language planning was an inevitable part of this process. Hence, language regulation served two conflicting value systems; it was endorsed by Moscow, but enforced in Estonia. "The Estonian language community had deep respect for Standard Estonian and its norms because it was the foundation of the Estonian identity. [...] Language served as a means for consolidating the nationality" (Laanekask and Erelt, 2003: 329).

Beginning in the 1960s, both the general interest in Estonian language and literature and local power to influence language planning increased. At the dawning of the Singing Revolution in the late 1980s, Estonian was given the status of a state language and in 1989, a Language Act was adopted. Estonia re-established its independence in 1991, along with the other Baltic countries.

In the immediate wake of the dissolution of the Union of Soviet Socialist Republics, the early 1990s were a period of laissez-faire, during which the fabric of social order was rewoven in most walks of life. English and Finnish, which had already begun to influence Estonian, now took centre stage. "Usage was liberated over a short period from the socialist but at the same time national rhetoric, being replaced by catchwords of consumerist society and direct foreign loans" (Laanekask and Erelt, 2003: 330). The initial response in the post-Soviet period was, understandably, to reverse Soviet policies in order to pave the way for a new order - both as a reaction to the authoritarian Soviet regime and as a statement of Estonian independence, openness and western orientation. In addition to this, 
the 1990s can be characterised as a time of construction of the new system, during which policies and laws were being worked out or finetuned; the transition to a new, capitalist democracy could not occur overnight. Hence, in social, economic and cultural life, much was left unregulated, and an attitude of individual independence and freedom of action prevailed. The lack of regulation also included less control over language use. As Laanekask and Erelt write, the primary goals in the early post-Soviet period were economic prosperity and individual freedom, both of which supported the proliferation of new authors and the lack of editing or proofreading. This reflected (a) a revisionist reaction to Soviet-style approaches, (b) a bow to the "language competence of any authors", and (c) a means of saving money (Laanekask and Erelt, 2003: 330).

\subsubsection{The new millennium}

At the advent of the new millennium, however, the pendulum began to swing back as Estonian society became more stable and the state was poised to join the European Union. This was paired with a renewed strengthening of ethnic feeling among Estonians at the time, which translated into an acute public debate over the issue of membership in the European Union. A public referendum was held in 2003, following nearly a year of active campaigning, in which the economy was the primary argument on both sides; the referendum was approved, with $63 \%$ in favor of joining the EU. Deutsche Welle reported "Estonia emphatically repudiated fears the country's dynamic and liberal economy would get mired in EU red tape if it joined the union"32. So in 2004, along with the other two Baltic countries, Estonia joined the EU and NATO.

32 http://www.dw.de/estonians-say-jah-to-the-eu/a-967912-1 
The EU red tape was matched by an increase of normativity within Estonia, in linguistic planning as in other spheres. In addition to membership in the European Union, the year 2004 also saw the adoption of the Estonian Language Strategy ${ }^{33}$, a document outlining policy with regard to language planning and use. The period since then has seen a number of strategy documents and monitoring reports, nationally funded programmes, awards, and other initiatives to support correct Estonian language usage, the development of terminology, and language teaching. After a period of little editing and loose oversight regarding usage, and following "numerous embarrassing failures", demand grew again for linguistic editing: media entrepreneurs hired editors again, and "more respectable publishing houses and periodicals started to pay more attention to editing" (Laanekask and Erelt, 2003: 330).

Alongside the stability of the Estonian state and strengthened ethnic feeling among Estonians, however, ethnic tensions also grew in the years 2006-2007. These culminated in the events known as pronksiöo, or 'Bronze Night', in April 2007. As the Estonian government made plans to move the Bronze Soldier, a monument dedicated to fallen Red Army soldiers, out of central Tallinn, groups of Estonia's young, ethnic Russians gathered to protest, and the emotionally charged symbolic event turned into ethnic riots.

Estonia's location on the border between Europe and Russia has meant both an advantage and strategic liability, located at a cultural and political crossroads throughout its history. This was a particular moment when several metadiscourses met and formed an explosive reaction:

...the Bronze Soldier chain of events was an ethnic counter-reaction to forceful Europeanization in the last decade, when

33 http://www.eki.ee/keelenoukogu/strat_en.pdf 
Estonia struggled to meet European standards in multiculturalism and political correctness in order to achieve EU membership. [...] Yet, [...] it was precisely the feeling of the threat of weakening ethnic identity and the blurring of boundaries between Estonians and Russophones that motivated small rightwing groups on both sides to look for measures to increase ethnic mobilization. (Ehala, 2009: 152)

Since then, tensions in ethnic relations have declined and language planning tends to include more attention focussed on developing Estonian terminology and teaching Estonian as a Foreign Language to non-ethnic Estonians. Hennoste advocates a "polylogical language model", which does not enforce any central sublanguage common to all Estonians, but rather accepts the multiplicity of co-existing language varieties, a model suited perhaps to the diverse, polyphonic society of today (Hennoste, 1999). More traditionalist language planners note that "languages without a strong backbone - without a standard language - have been lost, are nowadays in decline", adding that "in a small society [a standard language] strengthens the identity of both individual and society" (Laanekask and Erelt, 2003: 333). However, the central aims of language planning in contemporary Estonia are to "maintain the written language and to make the language users realize that the language planners do not ban or allow a certain form but they guide, recommend, and give advice" (Laanekask and Erelt, 2003: 334-335).

\section{Concluding thoughts}

The two periods of conservativism discussed here were both reactive, and both operated in the context of maintenance of Estonian in the face of a perceived threat. The conservative language 
regulation of these periods continued the general aims of earlier innovative language normativity: the search for national identity and common purpose. During the Soviet period, language regulation was one way to work within the system to protect the language, the most important symbolic carrier of Estonian identity. In the early 2000s, the conservative policies supported ethnic feeling, reacting to (1) an imported value system of multicultural tolerance seen to be imposed from the European Union, and (2) the continued Russophone presence within Estonia, which constituted a language community separated physically, due to the demographic inheritance of the USSR, and cognitively, thanks to the separate information spaces and discourses supported by Estonian and Russian-language media (cf Ehala, 2014). The late 1990s was a honeymoon period for integration but in the early 2000s, ethnic relations became restless.

We might conclude from this that the language planning pendulum, swaying between radical reforms and reactionary rigidity, has currently found a happy balance. That balance, if it lasts, suits language attitudes at large, deriving from the sense of an independent Estonian identity within the framework of a stable Europe. That stability allows for openness and freedom, paired with responsibility, and that independence supports the need for a certain amount of planning and prescriptivism to maintain a strong, standard language and safeguard its usage.

In 2010, Estonian President Toomas Hendrik Ilves revived a tradition of word coinage, dating back to the 1930s, reinstating a word competition also organised in 1972. The President's neologism competition was announced in order to stimulate the creation of good, simple Estonian words for complex, tongue-twisting loans borrowed from international and European lingo. Some very apt words have been invented through this scheme, and have even entered general usage, supported by their implementation by news anchors and other language popularisers. Foreign words such as 'infrastructure', 
'sustainability' and 'humanitarian aid' have been given viable, compact, homegrown alternatives with Estonian equivalents taristu, kestlikkus and toimeabi.

Interestingly, in the discourse surrounding the word competitions of the 2010s, no explicit mention is usually made of Aavik's principles of "good" Estonian language, yet the competition entries reveal that perhaps Aavik's deepest influence can be seen in the ways ordinary speakers think of "good language": it is self-evident that "good" Estonian words should be simple, clear and beautiful. Beauty may be in the ears of the listener, but Estonian boasts an astonishing amount of neologisms based on aesthetic principles which have stood the test of time and remained in fashion.

Language planning imposes values, but it also reflects cultural values of the times. It both mirrors and shapes ethnic identity in various ways. At different points in the development of the Estonian language and nation, forward-looking and back-facing ideologies have supported language planning, while leaving intact the fundamental insight underlying language reforms, renewal, planning and policy throughout the past two centuries: for the relatively small Estonian population, language and national identity cannot but go hand in hand.

\section{References}

Aavik, Johannes (1922). Puudused uuemas eesti luules [Shortcomings of recent Estonian poetry]. Tartu.

Aavik, Johannes (1924). Keeleuuenduse äärmised võimalused ['Extreme possibilities of language reform']. Tartu: Istandik.

Chalvin, Antoine (2010). Johannes Aavik et la rénovation de la langue estonienne. Paris: ADEFO/L'Harmattan.

Comrie, Bernard (1981). The Languages of the Soviet Union. Cambridge: Cambridge University Press. 
Ehala, Martin (2014). "Russian-speakers in the Baltic countries: Language use and identity". In: V.-A. Vihman and K. Praakli (eds.), Negotiating Linguistic Identity: Language and Belonging in Europe (Nationalisms across the Globe, 14). Oxford: Peter Lang.

Ehala, Martin (2011, October 19). Rahvustunne töötab rahvuse püsimisele vastu [National feeling works against the continuity of a nation]. Postimees. Retrieved February 3, 2014, from http://arvamus.postimees.ee/603222/martin-ehala-rahvustunne-tootab-rahvuse-pusimisele-vastu.

Ehala, Martin (2009). The Bronze Soldier: Identity Threat and Maintenance in Estonia, Journal of Baltic Studies, 40 (1): 139-158.

Ehala, Martin (1998). "How a man changed a parameter value: the loss of SOV in Estonian subclauses". In: R.M. Hogg, L. van Bergen (eds.). Historical Linguistics 1995 (Vol. 2): Germanic linguistics. Selected papers from the 12th International Conference on Historical Linguistics, Manchester, August 1995, pp. 73-88. Amsterdam: John Benjamins.

Elisto, Elmar (1948). Keelelisi küsimusi I. Tallinn.

Fichte, Johann Gottlieb. (1845). Reden an die deutsche Nation [Addresses to the German nation]. In I. H. von Fichte (ed.), Johann Gottlieb Fichte: Sämmtliche Werke (Vol. 7): Zur Politik, Moral und Philosophie der Geschichte [Collected works, vol. 7: On the politics, morality, and philosophy of history]. Leipzig: Mayer and Müller.

Helme, Martin (2011, October 20). Meid ohustab liigne avatus [We are in danger from too much openness]. Postimees. Retrieved February 3, 2014, from www. postimees.ee/604804/martin-helme-meid-ohustab-liigne-avatus.

Hennoste, Tiit (1999). Eesti keele arengud. Keel ja Kirjandus, 2, pp. 88-96.

Kamusella, Tomasz (2014). "Scripts and politics in modern Central Europe". In: V.-A. Vihman and K. Praakli (eds.), Negotiating Linguistic Identity: Language and Belonging in Europe (Nationalisms across the Globe, 14). Oxford: Peter Lang.

Kamusella, Tomasz (2009). The politics of language and nationalism in modern central Europe. Basingstoke, New York: Palgrave Macmillan.

Kruusvall, Jüri, Vetik, Raivo and Berry, John W. (2009). The Strategies of Inter-Ethnic Adaptation of Estonian Russians. Studies of Transition States and Societies, 1 (1), pp. 3-24.

Kurman, George (1968). The Development of Written Estonian. Indiana University Publications, Uralic and Altaic Series, vol. 90. Bloomington: Indiana University Press.

Laanekask, Heli and Erelt, Tiiu (2003). Written Estonian. In M. Erelt (ed.). Estonian Language. Linguistica Uralica Supplementary Series, vol. 1, pp. 273-342. Estonian Academy Publishers: Tallinn.

Leerssen, Joep. (2006). National thought in Europe: A cultural history. Amsterdam: Amsterdam University Press.

Piirimäe, Eva (2013, February 6). Ajalootüli peegeldab praegust Eesti rahvusliku identiteedi muutumist [Conflict over history reflects today's changing Estonian national identity]. Postimees. Retrieved February 3, 2014, from http://arvamus. postimees.ee/1128518/eva-piirimae-ajalootuli-peegeldab-praegust-eesti-rahvusliku-identiteedi-muutumist. 
Raag, Virve (1998). The Effects of Planned Change on Estonian Morphology. Studia Uralica Upsaliensia, 29. Acta Universitatis Upsaliensis: Uppsala.

Rosenplänter, J. (1813). Vorrede. Beiträge zur genauern Kenntniss des ehstnischen Sprache, I. Pärnu.

Spolsky, Bernard (2004). Language policy. Cambridge: Cambridge University Press.

Sutrop, Urmas (2008, March 14). Eesti keele suurim vaenlane on integratsioon [The greatest enemy of the Estonian language is integration]. Postimees. Retrieved February 3, 2014, from www.postimees.ee/1769817/urmas-sutrop-eesti-keele-suurim-vaenlane-on-integratsioon.

Tauli, Valter (1940). Maksva keelenormi kriitika ja muutmisettepanekud [Criticism and proposals for changes to the existing language norms]. Eesti keel, pp. 228-237 .

Valk, Aune (2011, October 12). Kosmopoliitsus sütitab eestlaste rahvuslikku uhkust [Cosmopolitanism fires up Estonians' national pride]. Postimees. Retrieved February 3, 2014, from www.postimees.ee/594458/valk-kosmopoliitsus-sutitab-eestlaste-rahvuslikku-uhkust.

Verschik, Anna (2008). Emerging Bilingual Speech: from Monolingualism to Code-Copying. London: Continuum.

Veski, Johannes Voldemar (1913). "Eesti kirjakeele edasiarendamise-teedest [Paths for continuing development of the Estonian standard language]". In: Voog I (Eestimaa Rahvahariduse-Seltsi Kirjanduse-Haruseltsi toimetused, nr. 15), pp. 99-120. Tallinn.

Vetik, Raivo (2011, October 20). Lõimumine eeldab koostegemist [Cooperation is a precondition to integration]. Postimees. Retrieved February 3, 2014, from www. postimees.ee/604802/raivo-vetik-loimumine-eeldab-koostegemist.

Vihman, Virve-Anneli and Barkhoff, Jürgen (2014). "Introduction: The shaping of linguistic identity in Europe". In: V.-A. Vihman and K. Praakli (eds.), Negotiating Linguistic Identity: Language and Belonging in Europe (Nationalisms across the Globe, 14). Oxford: Peter Lang.

Walsh, John (2014). "Pushing an open door? Aspects of language policy at an Irish university". In: V.-A. Vihman and K. Praakli (eds.), Negotiating Linguistic Identity: Language and Belonging in Europe (Nationalisms across the Globe, 14). Oxford: Peter Lang. 